\title{
ENTERIC VIRUSES, SOMATIC COLIPHAGES AND VIBRIO SPECIES IN MARINE BATHING AND NON-BATHING WATERS IN ITALY
}

L. Bonadonna ${ }^{1}$, R. Briancesco ${ }^{1}$, E. Suffredini ${ }^{2}$ A. Coccia $^{1}$, S. Della Libera ${ }^{1}$, A. Carducci ${ }^{3}$, M. Verani $^{3}$, I. Federigi ${ }^{3}$, M. Iaconelli ${ }^{1}$, G. Bonanno Ferraro ${ }^{1}$, P. Mancini ${ }^{1}$, C. Veneri ${ }^{1}$, E. Ferretti ${ }^{1}$, L. Lucentini $^{1}$, L. Gramaccioni ${ }^{4}$, G. La Rosa ${ }^{1}$

${ }^{1}$ Department of Environment and Health, Istituto Superiore di Sanità, Rome, Italy

${ }^{2}$ Department of Food Safety, Nutrition and Veterinary Public Health, Istituto Superiore di Sanità, Rome, Italy

${ }^{3}$ Department of Biology, University of Pisa, Pisa, Italy

${ }^{4}$ Ministry of Health, Directorate General for Prevention, Rome, Italy

\section{Corresponding author:}

Giuseppina La Rosa

Department of Environment and Health, Istituto Superiore di Sanità,

Viale Regina Elena 299, 00161 Rome, Italy

Telephone: +39.0649902718

Email: giuseppina.larosa@iss.it

ORCID: https://orcid.org/0000-0002-2657-100X

Keywords: bathing water, virus, somatic coliphages, Vibrio spp., microbial indicators 


\begin{abstract}
Microbial safety of recreational waters is a significant public health issue. In this study we assessed the occurrence and quantity of enteric viruses in bathing and non-bathing waters in Italy, in parallel with microbial faecal indicators, somatic coliphages and Vibrio spp.

Enteric viruses (aichivirus, norovirus and enterovirus) were detected in $55 \%$ of bathing water samples, including samples with bacterial indicator concentrations compliant with the European bathing water Directive. Aichivirus was the most frequent and abundant virus. Adenovirus was detected only in non-bathing waters. Somatic coliphages were identified in $50 \%$ bathing water samples, $80 \%$ of which showed simultaneous presence of viruses.
\end{abstract}

Vibrio species were ubiquitous, with 9 species identified, including potential pathogens ( $V$. cholerae, V. parahaemoylticus and V. vulnificus).

This is the first study showing the occurrence and high concentration of Aichivirus in bathing waters and provides original information, useful in view of a future revision of the European Directive.

Keywords: bathing water; estuary; enteric viruses; somatic coliphages; microbial indicators; Vibrio spp 


\section{Introduction}

Faecal contamination of marine water can lead to potential public health risks for humans due to the presence of enteric pathogens. Waterborne diseases, including gastroenteritis, infections of the upper respiratory tract, and of eyes, ears, and skin, can be acquired by swimmers exposed to contaminated recreational waters.

The global burden of disease associated with bathing in coastal polluted waters has been estimated to be about 120 million cases of gastrointestinal disease and 50 million cases of respiratory diseases each year (Shuval, 2003). More recently, DeFlorio-Barker and coworkers estimated that 90 million illnesses due to recreation events involving surface water occur annually in the United States, resulting in a cost of $\$ 2.2-\$ 3.7$ billion per year (DeFlorio-Barker et al., 2018). According to a recent systematic review and meta-analysis there is evidence that a number of infections are acquired from bathing in coastal waters, and that bathers have a greater risk of experiencing a variety of illnesses compared with non-bathers (Leonard et al., 2018).

Among waterborne pathogens, viruses are recognized as a major cause of disease outbreaks in recreational waters (Begier et al., 2008; Schets et al., 2018; Sinclair et al., 2009; Yoder et al., 2008a; Yoder et al., 2004; Zlot et al., 2015).

Bathing water quality monitoring was first defined in 1975 in the EU Bathing Water Directive 76/160/EEC (EU, 1976), modified in 2006 by the EU Directive 2006/7/EC (EU, 2006). According to this Directive, fecal indicator organisms (E. coli, EC, and Intestinal Enterococci, IE) are used for bathing waters classification. Based on their concentrations, bathing waters are classified as excellent (EC: $\leq 250$ colony forming units (CFU)/100 ml; IE: $\leq 100 \mathrm{CFU} / 100 \mathrm{ml}, 95$ th percentile), good EC $(\leq 500 \mathrm{CFU} / 100 \mathrm{ml}$; IE: $\leq 200 \mathrm{CFU} / 100 \mathrm{ml}$, 95th percentile), sufficient (EC: $\leq 500$ CFU/100 ml; IE: $\leq 185 \mathrm{CFU} / 100 \mathrm{ml}$, 90th percentile) or poor (values worse than for the latter).

Epidemiological studies support the evidence that enteric and respiratory diseases among bathers increase steadily with increasing concentrations of indicator microorganisms of faecal pollution, 
compared with unexposed non-bathers (Shuval, 2003). On the other hand, it is known that indicator

microorganisms do not necessarily correlate well with viral pathogens and protozoa, particularly when faecal indicator concentrations are low, since these groups show different survival capacity and transport behaviour (Figueras et al., 1997; Figueras and Borrego, 2010; Ortega et al., 2009). Enteric viruses are responsible for waterborne disease worldwide, a growing number of them being associated with recreational activities, reviewed in (Bonadonna and La Rosa, 2019; Sinclair et al., 2009). Human viruses most commonly associated with recreational waterborne illnesses are noroviruses (NoV), adenoviruses (AdV), and enteroviruses (EV) (La Rosa et al., 2012).

Adenoviruses, members of the Adenoviridae family, are double-stranded DNA viruses with a worldwide distribution. They are associated with a range of diseases, including respiratory tract syndromes, gastrointestinal, ophthalmologic, genitourinary, and neurologic diseases, reviewed in (La Rosa G. and Suffredini, 2018). In patients with impaired immune responses, the disease can be associated with high morbidity and mortality. Adenoviruses have been detected in various water environments worldwide including wastewater, drinking water, ocean, river and swimming pools (Allard and Vantarakis, 2017). AdV have been found to be responsible for several recreational outbreaks of waterborne illness, the majority of these associated with swimming pools (Sinclair et al., 2009), and have been suggested as possible index organisms for viral pathogens (Gerba et al., 2002; Katayama et al., 2008; Verani et al., 2019). In comparison to RNA viruses, AdVs are more resistant to environmental inactivation and show resistance to many chemical/physical agents and to UV light.

Enteroviruses, members of the Picornaviridae family, are classified into four species (EV-A, -B, -C and $-\mathrm{D}$ ), including both poliovirus and non-polio enteroviruses. They are responsible for a wide spectrum of diseases in people of all ages, including subclinical or mild illness, like colds and fever, or more severe disorders like paralysis, meningitis, and cardiomyopathy. Enterovirus infections are a significant cause of morbidity and mortality throughout the world, in particular for infants and young children; they cause an estimated 10-15 million symptomatic infections per year in the US 
alone. Enteroviruses have been detected in different water environments including raw and treated

sewage, groundwater, seawater, and fresh water environments (Betancourt and Shulman, 2019; Rajtar et al., 2008). Coxsackievirus and echovirus were found to be responsible for outbreaks associated to viral contamination of lakes, seawater, and swimming pools (Bonadonna and La Rosa, 2019; Sinclair et al., 2009).

Noroviruses are single-stranded RNA viruses belonging to the Caliciviridae family, responsible for sporadic and epidemic gastroenteritis in humans. The World Health Organization estimated that norovirus causes annually 685 million cases of acute gastroenteritis, making it the most common cause of acute gastroenteritis worldwide. These viruses are transmitted through the fecal-oral route, leading to high viral loads in sewages. The presence of $\mathrm{NoV}$ in sewage and water environments impacted by sewage, including surface waters and seawater, has been widely reported worldwide. Waterborne outbreaks associated with recreational activity in natural waters (lakes, rivers, hot spring) and in pools and fountain have been described (Bonadonna and La Rosa, 2019; Sinclair et al., 2009).

More recently, the occurrence of Aichivirus (AiV) in water environments has raised interest. AiV is a member of the Kobuvirus genus (Picornaviridae family), responsible of gastroenteritis in humans through contaminated food or water (Kitajima and Gerba, 2015a). It has been detected in various types of water environments (sewage, river water, and groundwater) worldwide, frequently in higher frequency and greater abundance than other enteric viruses (Haramoto et al., 2018; Kitajima and Gerba, 2015b). However, AiV presence has never been investigated in marine waters.

Somatic coliphages are viruses that infect $E$. coli. The high concentration of coliphages in sewage and other faecal contaminated waters, the easy, fast and economical methods of detection and enumeration, their persistence in water and their resistance to treatments comparable to that of viruses make coliphages good indicators for a wide range of applications. Thus coliphages may also be helpful in the quality control of surface water used for bathing. Possible correlations between the 
concentration of coliphages and human viruses in water have been studied, though with disparate results (Gomila et al., 2008; Lucena et al., 2003).

In addition to pathogens from allochthonous sources, also autochthonous marine bacteria can cause disease in humans. Vibrios are natural inhabitants of marine coastal waters and, occasionally, of brackish inland lakes and streams, where they exist as free-living microorganisms and in association to zooplankton and higher organisms (Bonadonna et al., 2002; Esteves et al., 2015; Kirchberger et al., 2016; Neogi et al., 2018; Takemura et al., 2014). Species that cause illness in man include $V$. cholerae, causing gastrointestinal illness (including cholera, generally associated with contaminated seafood), V. parahaemolyticus, causing gastroenteritis, V. vulnificus, responsible of skin infections, septicaemia and death, and $V$. alginolyticus, etiological agent of wound, ear and eye infections. Wound and ear infections were the most recurrent infections associated with Vibrio in bathing water in Europe (Andersson and Ekdahl, 2006; Frank et al., 2006; Schets et al., 2006) and USA (Dziuban et al., 2006; Yoder et al., 2008b) while Vibrio-associated gastroenteritis through recreational water exposure is rare (Yoder et al., 2008b).

There is evidence that human Vibrio illnesses are increasing worldwide, associated with climatic anomalies, such as heat wave conditions (Baker-Austin et al., 2016; Baker-Austin et al., 2018). The European Centre for Disease Prevention and Control (ECDC) developed a platform to monitor the environmental suitability of coastal waters for Vibrio spp. using remotely sensed Sea Surface Temperature (SST) and salinity as an early warning system. In fact, the risk of further Vibrio infections is increasing due to climate change (Semenza et al., 2017). The lack of a quantitative correlation between autochthonous species such as vibrios and bacterial indicator parameters suggests that bathing water legislation based on sole faecal indicators does not provide sufficient protection for bathers against vibrios infections (Badley et al., 1990; Dumontet et al., 2000). This fact, combined with the scarcity of recent prevalence data on Vibrio species along Italian coasts, support the investigations on the occurrence of these bacteria and the factors affecting their spreading. 
Herein we report the results of a study on virological and bacteriological quality of bathing and non-

bathing waters in Italy. Occurrence and number of adenovirus, enterovirus norovirus, aichivirus and somatic coliphages were examined in parallel with the traditional faecal bacterial indicators. Contemporaneously, number and types of potentially human pathogenic Vibrio species and their relation to environmental conditions (e.g. water temperature and salinity) were investigated.

\section{Material and methods}

Study area and sample collection

Two sites, site A on the Adriatic Sea and site B on the Tyrrhenian Sea respectively, were monitored from May to September 2018 (Figure 1). The sampling points were along sandy coasts with shallow sea near the shore. For each site, three sampling points were selected: one in non-bathing waters (point zero) at the estuary of a stream receiving treated urban wastewaters from a Wastewater Treatment Plant (WTP) located less than 1000 meters upstream, and two (points 1 and 2) in the contiguous bathing waters (100-250 mt from the estuary, at its left and at its right). In particular, in site A, the Marano estuary receives the outfall of Riccione WTP and Rimini Nord along-shore area; in site B, the Fosso Grande receives the outfall of Ardea WTP, and is known as polluted channel. A total of 20 bathing and 10 non-bathing water samples were collected with monthly sampling. Water samples for bacteriological analyses (1 L) and for virological analyses $(20 \mathrm{~L})$ were collected in sterile bottles. All samples were taken at a depth of $20 \mathrm{~cm}$ below the surface. Environmental conditions (water temperature, salinity and $\mathrm{pH}$ ) were recorded at sampling. Records of weather and marine conditions were also kept. Samples were transported within the day, under temperature controlled conditions $\left(\leq 22^{\circ} \mathrm{C}\right)$, to the laboratory. Upon arrival, samples were immediately analysed for bacteriological analysis and were stored under refrigerated conditions for virological analyses, that were initiated within 24 hours.

Bacteriological analyses 
Detection of E. coli and intestinal Enterococci was carried out by miniaturized cultural MPN methods (Colilert 18 and Enterolert E, Idexx, USA).

For Vibrio detection, water samples (from 0.1 to $100 \mathrm{~mL}$ volumes) were analysed by membrane filtration technique. Membranes were placed on Chromatic $^{\mathrm{TM}}$ Vibrio medium (Liofilchem, Italy) and incubated at $37^{\circ} \mathrm{C}$ for $24-48$ hours. Presumptive Vibrio colonies were counted separately according to their morphology (mauve colonies for $V$. parahaemolyticus, green blue, turquoise or blue for V.vulnificus/V.cholerae, and colourless colonies for $V$. alginolyticus), while colonies with other morphologies (orange or deep violet) were counted but not furtherly tested. Details of the selection and screening procedure are reported in Supplementary Material. Depending on the abundance of the specific colony type, a percentage ranging from 10 to $25 \%$ of the colonies of the same morphology was isolated from each plate and subjected to biochemical confirmation tests (Gram staining, oxidase test, and string test). Some biochemical positive isolates (about 40\%) were identified by miniaturized kits (bioMerieux, France) while the others were subjected to molecular identification. Briefly, for each isolate, a single colony was suspended in ultrapure water $(0.2 \mathrm{~mL})$, heat-lysed $\left(95^{\circ} \mathrm{C}\right.$ for $\left.10 \mathrm{~min}\right)$, centrifuged to sediment debris $(2 \mathrm{~min}$ at $10.000 \times \mathrm{g})$ and $1.5 \mu \mathrm{L}$ of the supernatant was used for the PCR amplification of the $r p o B$ gene zhang (Ki et al., 2009). The 730 bp PCR products were purified with Montage PCRm96 Micro well Filter Plates (Millipore, Burlington, USA) and DNA sequencing was performed on both strands (BioFab Research, Rome). Consensus sequences were assembled from the raw forward and reverse electropherograms, using the Molecular Evolutionary Genetics Analysis (MEGA) software, version 7.0. Species identification was evaluated using NCBI BLAST (Basic Local Alignment Search Tool, available at: http://blast.ncbi.nlm.nih.gov/Blast.cgi).

In addition to Vibrio spp. count, a species-specific enumeration of $V$. parahaemolyticus was performed by colony hybridization. Briefly, $10 \mathrm{ml}$ of each sample were high-speed centrifuged $(\geq 10.000 \times g$ for $30 \mathrm{~min}$ ) to sediment seawater bacteria, the upper $9 \mathrm{ml}$ of water were carefully withdrawn and the remaining milliliter was vortexed to resuspend bacteria, spread on trypticase soy 
agar medium added with $\mathrm{NaCl}$ to $3 \%$ (TSA-S), and subsequently incubated at $37^{\circ} \mathrm{C}$ for $18 \mathrm{~h} . V$. parahaemolyticus enumeration was then performed as previously described (Suffredini et al., 2014).

\section{Virological analyses}

Somatic coliphages were detected by single-agar-layer (SAL) plaque assay, according to the USEPA Method 1602. E. coli ATCC 13706 strain was used in the assay. Five mL aliquots of each sample were directly analysed. After an overnight incubation, plaques were counted and summed for all plates from a single sample. The quantity of coliphages in a sample was expressed as plaque forming units (PFU)/100 mL.

Enteric viruses were concentrated using the adsorption-elution procedure with electronegative filters (La Rosa et al., 2017a). Before concentration, all samples were artificially contaminated with Mengovirus used as a sample process control. The recovery rate for Mengovirus was calculated as the ratio between the number of genome copies (g.c.) that were recovered after concentration and the g.c. of viral stock used to spike the samples, as previously described (Costafreda et al., 2006). Before concentration, the $\mathrm{pH}$ of the sample was adjusted at 3.5 with $\mathrm{H}_{2} \mathrm{SO}_{4}$; then, $20 \mathrm{~L}$ of water were flowed through a standard filter apparatus containing a sterile electronegative filter (Sartorius Membrane Filter Cellulose Nitrate 11306-142-G), using a peristaltic pump and a flow rate of 0.5 $\mathrm{L} / \mathrm{min}$. For virus elution, $50 \mathrm{~mL}$ of $3 \%$ beef extract $\mathrm{pH} 9.5$ was recirculated through the filters for 20 min. The $\mathrm{pH}$ was then neutralized with $\mathrm{HCl} 1 \mathrm{~N}$. A secondary concentration step was performed by PEG precipitation. PEG 6000 and $\mathrm{NaCl}$ were added to reach final concentrations of $10 \%$ and $1.6 \%$ w/v, respectively. The mix was incubated at $4^{\circ} \mathrm{C}$ for $14-18 \mathrm{~h}$ and then centrifuged at $7000 \times g$ for 30 min at $4^{\circ} \mathrm{C}$. The supernatant was discarded, and the pellet dissolved in $10 \mathrm{~mL}$ PBS pH 7.4. The concentrate was divided into two aliquots of $5 \mathrm{~mL}$, one of which immediately subjected to genome extraction, the other stored at $-80{ }^{\circ} \mathrm{C}$ for viral cell culture purposes.

Nucleic acid extraction and purification were performed using the NucliSens extraction kit (BioMerieux, Paris, France) according to the manufacturer's instructions, and eluted nucleic acids 
$(100 \mu \mathrm{L})$ were stored at $-80^{\circ} \mathrm{C}$ until molecular analysis. Following RNA/DNA extraction, all samples underwent PCR amplification by real-time RT-qPCR to detect and quantify NoV, EV, AiV, and by real-time qPCR for AdV. Analysis for NoV, EV, AiV and AdV were conducted with previously described reaction conditions (Fuhrman et al., 2005; Hernroth et al., 2002; ISO, 2017; Kitajima et al., 2013) and the panel of primers and probes reported in Table 1. Each sample was assayed in duplicate using $5 \mu \mathrm{L}$ of undiluted nucleic acid extract in a final volume of $25 \mu \mathrm{L}$. Two negative controls were included in each assay. Presence of PCR inhibitors was ruled out using an external amplification control (in vitro synthesized RNA) as described in ISO 15216 (ISO, 2017). Samples showing an inhibition $\geq 50 \%$ were subjected to further purification by mean of repetition of the DNA/RNA binding and washing steps of the NucliSens extraction system. Tenfold dilutions of plasmids DNA containing the region targeted by real-time PCR primers were used for standard curve construction (acceptability criterion: slope between -3.1 and -3.6 and $\mathrm{R}^{2}$ correlation coefficient $\geq 0.98$ ). All RT-qPCR reactions were conducted using the UltraSense one-step qRT-PCR System (Invitrogen), while qPCR reactions were prepared using the Hydra Probe qPCR Master Mix (BioLab, Italy). Molecular biology water served as a non-template control. Real-time PCR were conducted on a QuantStudio 12K instrument (Thermo Scientific).

Qualitative nested (RT)-PCR assays were performed for molecular characterization of enteric viruses. NoV (GI and GII), EV, AdV, and AiV were analysed using broad range primers shown in Table 1. A final mixture of $25 \mu \mathrm{L}$ was prepared for the first PCR with $2 \mu \mathrm{L}$ of RNA and 10 pmol of forward and reverse primers, using the MyTaq One Step RT-PCR kit (Bioline Ltd, London, UK) for EV detection and the SuperScript ${ }^{\mathrm{TM}}$ IV One-Step RT-PCR System (Invitrogen) for NoV GI, NoV GII and AiV detection. The nested PCR was performed in $25 \mu \mathrm{L}$ of PCR reactions with the MyTaq Red Mix (Bioline Ltd, London, UK) and Platinum Green Hot Start PCR Master Mix (Invitrogen) respectively, using one $\mu \mathrm{l}$ of the product from the first cycle as a template. For AdV, the first and the nested cycles were both prepared using the MyTaq Red Mix. Standard precautions were taken to prevent cross-contamination of samples. Positive and negative controls were regularly used. 
PCR products of the expected size were purified with Montage PCRm96 Micro well Filter Plates (Millipore, Burlington, MA, US) and confirmed by sequencing both strands (BioFab Research). Consensus sequences were assembled as previously described using the MEGA software v7.0. The relatedness of sequences was evaluated using NCBI BLAST (Basic Local Alignment Search Tool, available at: http://blast.ncbi.nlm.nih.gov/Blast.cgi).

\section{Cell culture for enteric viruses}

Cell cultures were used to assess the infectivity of adenovirus using A549 cells. To this end, $5 \mathrm{~mL}$ of PEG/concentrated water samples were decontaminated with chloroform and added to $7 \mathrm{~mL}$ of the culture medium, which was added to A549 cells (ECACC) cultured in Dulbecco's modified Eagle's medium (Euroclone) supplemented with $2 \%$ of fetal bovine serum (Euroclone). The cell cultures were incubated at $37^{\circ} \mathrm{C}$ with $5 \%$ of $\mathrm{CO}_{2}$ and observed daily under an optical microscope for 2 weeks until detection of cytopathic effects, followed by two subsequent confirmation steps (Carducci et al., 2009).

\section{Statistical analysis}

Descriptive statistics (average, median, standard deviation, etc.) were calculated for environmental parameters, bacteriological parameters (fecal indicators, Vibrio spp.) and somatic coliphages using the XlStat software (v 2019.1.1, Addinsoft, Boston, US). To assess the degree of agreement (DoA) between bacteriological and virological results, inter-rater reliability (expressed as Kappa) was calculated comparing detection of enteric viruses to: i) detection of coliphages; ii) detection of fecal indicators at levels corresponding to a bathing water class 'poor' according to the EU Directive; iii) detection of fecal indicators at levels corresponding to a bathing water class equal or worse than 'sufficient' according to the EU Directive. Based on Kappa results, the DoA was classified as slight (0-0.20), fair $(0.21-0.40)$, moderate $(0.41-0.60)$, substantial $(0.61-0.80)$ or almost perfect $(0.81-$ $1.00)$. 
Moreover, correlation of quantitative values of E. coli, intestinal Enterococci, somatic coliphages

and enteric viruses in bathing waters was assessed through calculation of the Pearson correlation coefficient $(r)$. For this calculation AiV were selected among enteric viruses, being the group with the highest number of positive, quantifiable results. Pearson correlation of quantitative values of Vibrio spp., E. coli, intestinal Enterococci and physical-chemical parameters in bathing waters was also performed.

Finally, to assess the accuracy of bacteriological parameters in predicting the presence of enteric viruses in bathing waters, the positive predictive value (PPV) and the negative predictive value (NPV) were calculated for the aforementioned three categories (coliphages, fecal indicators class 'poor', fecal indicators class 'sufficient' or worse). Kappa values, PPV and NPV were calculated using the GraphPad Software QuickCalcs online tool (https://www.graphpad.com/).

\section{Results}

\section{Environmental parameters}

Environmental conditions at sampling time are reported in Supplementary Material. In bathing sites, water temperature, $\mathrm{pH}$ and salinity were, on average, $23.7^{\circ} \mathrm{C}$ (range $19.9^{\circ} \mathrm{C}-28.8^{\circ} \mathrm{C}$ ), 8.23 (range $8.00-8.68$ ) and $33.8 \%$ (range $26.0 \%$ - 40.0\%o), respectively, with no significant difference between the two sampling sites on the Adriatic Sea and the Tyrrhenian Sea. In estuaries, both average water temperature and $\mathrm{pH}$ were close to those registered in the adjacent bathing areas (23.1 ${ }^{\circ} \mathrm{C}$ and 8.01 , respectively) while, as presumable, salinity was significantly lower $(20.2 \%)$.

\section{Bathing waters}

The level of microbial indicators in bathing waters met the requirements established by the EU Directive in 14 out of 20 samples (70\%), while 6 samples (4 from the Tyrrhenian and 2 from the Adriatic coast), collected in July ( $n=1)$, August $(n=4)$, and September $(n=1)$ exceeded the limits set 
for 'sufficient' waters for E. coli and/or Enterococci, and were therefore of poor quality (Table 2 and Figure 2).

Quantitative and qualitative results for enteric viruses and somatic coliphages are summarized in Table 2. For virological analysis, sample recovery ranged from $0.7 \%$ to $95.6 \%$, with an average of 14.8\%. PCR inhibition was present in 6 out of 30 samples, which required an additional RNA purification to remove inhibitors. Combining results obtained by nested and real-time PCR, enteric viruses were detected in 11/20 (55\%) bathing water samples, of which 6 compliant with the Directive for microbial indicators (status of at least 'sufficient') and therefore suitable for bathing according to the current legislation. Norovirus was detected in 5/20 (25\%) bathing water samples, with four GII-positive and one GI-positive samples, the latter characterized by sequencing as GI.4. Viral loads for NoV were overall low, the highest concentration being 3.2 genome copies (g.c.)/L. Aichivirus was detected in $6 / 20(30 \%)$ bathing water samples with high viral loads, compared to noroviruses, reaching up to 1100 g.c./L. All AiV-positive samples were characterized as AiV-1-B by amplicon sequencing. One sample was positive for EV (5\%), but genome copies were below the quantification limit; AdV was never detected in bathing waters.

Somatic coliphages were detected in 10/20 bathing water samples (Table 2), with higher counts found in August (up to $2120 \mathrm{PFU} / 100 \mathrm{~mL}$ ) and an average of $36 \mathrm{PFU} / 100 \mathrm{~mL}$ and $280 \mathrm{PFU} / 100$ $\mathrm{mL}$ in the Adriatic and Tyrrhenian coasts, respectively.

Simultaneous presence of viruses and coliphages was detected in eight bathing water samples. Overall, the degree of agreement (DoA) between these two parameters was moderate (Kappa = 0.500) and comparable to the DoA of enteric viruses and classification of bathing areas (waters classification 'poor': Kappa= 0.327, DoA fair; waters classification equal or worse than 'sufficient': Kappa $=0.510$, DoA moderate). Similarly, a predictive value for the presence of enteric viruses of $80.0 \%$ and $87.5 \%$ (PPV) and $70.0 \%$ and $66.7 \%$ (NPV) was shown by somatic coliphages and by a class equal or worse than 'sufficient' of bathing waters, respectively. Given the limited extension of sampling in the present study, a larger number and variety of samples from bathing waters should 
be tested to assess predictive capacity of these factors with regard to presence of enteric viruses.

Quantitative levels of enteric viruses (AiV) did not show any significant correlation with other microbial parameters in bathing waters (correlation coefficient $r=-0.028,-0.059$ and -0.048 with EC, IE and somatic coliphages, respectively). On the other hand, a weak and a strong correlation was found between somatic coliphages and EC $(r=0.162)$ or IE $(r=0.934)$, respectively. No correlation was also found among bacterial indicators concentration and environmental parameters as water temperature, salinity and $\mathrm{pH}$ (correlation coefficient $r$ ranging between -0.271 and 0.023 ; see Supplementary Material).

Vibrio species were ubiquitous and numerous in bathing sites, where they were detected in 17/20 samples $(85 \%)$, with concentrations ranging from undetectable to $1.7 \times 10^{4} \mathrm{CFU} / 100 \mathrm{~mL}$ (Table 3 ). Higher counts were detected from July to September and particularly in August (Figure 3, panel A), when concentrations of $10^{4} \mathrm{CFU} / 100 \mathrm{~mL}$ were exceeded in the seashore of Riccione. Overall, the mean concentration of Vibrio spp. in the Adriatic Sea was of the same magnitude order than along Tyrrhenian coast $\left(4.2 \times 10^{3}\right.$ and $1.3 \times 10^{3} \mathrm{CFU} / 100 \mathrm{~mL}$, respectively). No significant correlation was found among Vibrio spp. concentration and fluctuations of temperature and salinity (correlation coefficient $r=-0.192$ and 0.069 with temperature and salinity, respectively), while a positive correlation was found between Vibrio spp. and E. coli in bathing areas (correlation coefficient $r=$ 0.861, see Supplementary Material).

A total of eight species were identified by sequencing analysis in bathing waters: V. alginolyticus, V. campbellii, V. cholerae, V. diabolicus, V. harveyi, V. owensii/hyugaensis, V. parahaemolyticus, and $V$. rotiferanius. The most frequently detected species was $V$. harvey (13/20 samples), followed by $V$. cholerae and $V$. parahaemolyticus, equally detected (9 samples). With regard to the latter, speciesspecific counts showed low concentrations, ranging from undetectable to $20 \mathrm{CFU} / 100 \mathrm{~mL}$, with the highest values corresponding to samples taken in August in the Ardea site (data not shown). 
Microbial indicators in the samples collected at the estuaries of the streams were, as expected,

higher than in bathing waters (Table 2 and Figure 2), exceeding $4800 \mathrm{MPN} / 100 \mathrm{~mL}$ for EC in August, and reaching 2827 MPN/100 mL for IC in September. However, values below the detection limit for both EC and IC were recorded for some samples in May and in June.

Enteric viruses were detected in 7/10 (70\%) non-bathing waters. NoV was detected in 3/10 (30\%) samples, with low viral loads (up to 13 g.c./L), while Aichivirus was detected in 6/10 (60\%) samples with viral loads up to 1860 g.c./L, all characterized as AiV1-B by amplicon sequencing. Adenovirus, characterized as type 41, was detected in two estuarine samples (20\%); cell culture of these sample concentrates confirmed the absence of viable or culturable adenoviruses.

Somatic coliphages were detected in 7/10 non-bathing waters (up to $3560 \mathrm{PFU} / 100 \mathrm{~mL}$ in August) and an average of $172 \mathrm{PFU} / 100 \mathrm{~mL}$ and $840 \mathrm{PFU} / 100 \mathrm{~mL}$ at the site of Riccione and at the site of Ardea, respectively. Simultaneous presence of enteric viruses and somatic coliphages was detected in six samples.

Vibrio species were detected abundantly also in estuary samples (8/10 samples), with loads up to $1.0 \times 10^{4} \mathrm{CFU} / 100 \mathrm{~mL}$ and an average concentration of $2.7 \times 10^{3} \mathrm{CFU} / 100 \mathrm{~mL}$ (Table 3). High counts were obtained in July in the site of Riccione and Vibrio concentrations showed an irregular trend during the sampling period (Figure 3, panel B). Correlation of Vibrio and E. coli counts $(r=0.739)$ was confirmed as per bathing waters. In these samples the species detected included $V$. alginolyticus, V. campbellii, V. cholerae, V. harveyi, V. owensii/hyugaensis, V. parahaemolyticus, and $V$. vulnificus, with the prevalence of the first one.

\section{Discussion}

Currently, microbiological quality monitoring of bathing waters is solely based on the measurement of faecal indicator organisms, Escherichia coli and intestinal enterococci, as an alternative to pathogens detection. Moreover, the number of viral pathogens potentially responsible for waterborne illness is significant and therefore testing for all potential hazards could not be feasible. 
In this study, a survey was conducted to determine enteric viruses' occurrence and quantity in

recreational waters together with faecal indicator bacteria, autochthonous bacteria such as vibrios and somatic coliphages. Assessing the presence of viruses in water is not defined by the current legislation. The previous EU Bathing Water Directive 76/160/EEC (EU, 1976) recommended enteroviruses among parameters to be tested, requiring that $95 \%$ of samples taken during the bathing season should not contain enteroviruses in $10 \mathrm{~L}$ of water. The current Bathing Water Directive 2006/7/EC identifies only two parameters for the monitoring and assessment of bathing water quality and for their classification, intestinal enterococci and Escherichia coli.

Results of the present study confirm previous finding showing that microbiological parameters defined in the current Bathing Water Directive have low predictive capability for the presence of human viruses in coastal waters. Indeed, enteric viruses were found in 11/20 (55\%) of bathing water samples, including samples considered safe based on microbial indicator concentrations. Interestingly, $\mathrm{AiV}$ were the most frequent and numerous virus detected along both the sampling sites, found in $30 \%$ of bathing water samples and $60 \%$ of non-bathing water samples with high viral loads (up to 1100 g.c./L and 1860 g.c./L, respectively). To our knowledge, AiV presence in bathing waters has never been demonstrated before. These viruses have been detected, however, in various types of environmental samples worldwide, such as sewage, river water, groundwater, and shellfish, in higher frequency and greater abundance than other human enteric viruses, suggesting that it could potentially be proposed as an indicator of viral contamination in the environment (Kitajima and Gerba, 2015b). In Italy, we recently found AiV in $98 \%$ of urban wastewater samples with concentrations reaching $2.3 \times 10^{6}$ genome copies/L (Suffredini et al., 2019), suggesting that AiV can likely contaminate other water environments impacted by sewage, including bathing waters. Moreover, AiV were detected in $8 \%$ of mussels collected in harvesting areas in the Campania region in Southern Italy (Fusco et al., 2017), suggesting a diffuse presence of these viruses in marine waters. The genotypes distribution detected in environmental water samples varies in different geographical regions. In this study only AiV1-B was detected, which is the genotype 
usually more commonly detected in the European countries (Di Martino et al., 2013; Lodder et al., 2013) and South America (Alcala et al., 2010; Burutaran et al., 2016) while genotype A is more frequently detected in Asia (Kitajima et al., 2011; Kitajima and Gerba, 2015b) and Africa (SdiriLoulizi et al., 2010).

Adenovirus was detected in two samples in non-bathing areas but was never detected in bathing water samples. Among the waterborne viruses, AdV can be considered as an index pathogen, owing to its abundance in sewage and persistence in the environment (Verani et al., 2019). During the EU FP6 Project VIROBATHE (2005-2007), AdV appeared to be a promising viral indicator for bathing water quality, since it was detected in $36 \%$ of recreational (fresh and marine) waters in the participant European countries (Wyer et al., 2012; Wyn-Jones et al., 2011), with loads of $3.2 \times 10^{3}$ g.c./L water on average (and up to $9.1 \times 10^{4}$ ) in marine samples. Moreover, $47 \%$ of marine waters positive for AdV contained infectious viruses. More recently, Verani and co-workers found AdV in $21 \%$ of seawater samples in Italy, with concentration up to $10^{2}$ g.c./L (Verani et al., 2019). In the light of these results, the absence of positive samples in bathing waters in this study was unexpected. To confirm negative results, different molecular tests were used (date not shown), and inhibition in negative samples was excluded. It is however important to consider that negative findings might also be the result of the small sample size of the study.

Norovirus was detected in $25 \%$ of bathing water samples, at low concentrations, also in samples considered safe based on microbial indicators concentrations. The VIROBATHE Project detected NoV in $9.4 \%$ of recreational water samples, and almost all the norovirus GI-positive samples were found in four sites in Italy (Wyn-Jones et al., 2011). More recently, NoV was detected in seawater samples from shellfish production areas and water samples from nearby underwater sewage discharge points in Italy (La Rosa et al., 2017b). Our study therefore confirms previous studies showing NoV circulation in seawater.

Enteroviruses were detected only in one bathing water sample. In Italy, EV have been identified in raw and treated wastewaters (La Rosa G. et al., 2010; Pellegrinelli et al., 2013; Pellegrinelli et al., 
2017; Pennino et al., 2018), river (La Rosa et al., 2017c), groundwater used for irrigation (De Giglio

et al., 2017). Only one study shows the presence of enteroviruses in seawater samples in Italy. Positive samples were detected in $32.6 \%$ by cell culture techniques, most frequently in the summer months (Pianetti et al., 2000).

In the present study, $30 \%$ of bathing water samples positive for enteric viruses showed safe counts for E. coli and Enterococci, therefore suitable for bathing according to the current legislation. The presence of enteric viruses in recreational waters compliant for bacterial indicators is reported worldwide (Love et al., 2014; Wyn-Jones et al., 2011), indicating that current standards defined in the Bathing Water Directive, based on EC/IE levels, have low predictive capability for the presence of human viruses in these waters. Testing for somatic coliphages presents an alternative to testing for viral pathogens, as they share similar morphologies, are more environmentally stable than faecal indicator microorganisms, are numerous in human faecal waste, and can be detected by simple and inexpensive culture-based detection methods. Different studies suggest a likely relationship between coliphages and increased risk of gastroenteritis for bathers (Abdelzaher et al., 2011; Griffith et al., 2016; Wiedenmann et al., 2006). However, reliable data on the meaning of enumerating coliphages to predict the presence of intestinal pathogens, in particular viruses, are contradictory and often incomplete. In this study a total of 14 samples (47\%) showed simultaneous presence of somatic coliphages and enteric viruses, and coliphages detection showed a positive predictive value for enteric viruses presence of $80.0 \%$, though similar predictive values were obtained with bacterial fecal indicators when using more strict contamination thresholds. Given the limitation of sampling size in this study, a predictive capacity of coliphages towards virus presence in bathing waters should be assessed through more extensive surveys or through meta-analysis studies, so as to include a wider variability of bathing sites and environmental conditions.

Because of their ubiquity and their potential as pathogens Vibrio were also investigated in this study. These bacteria are autochthonous in marine and estuarine environments (Baker-Austin et al., 2018; Suffredini and Caburlotto, 2015). They are also commonly present in shellfish and other 
seafood (Froelich and Noble, 2016; Huehn et al., 2014; Odeyemi, 2016; Romalde et al., 2014). The

Vibrio genus includes more than 100 species (Romalde et al., 2014), present in the environment as free-living or associated with different substrata. Some species are associated with human cases of ear and wound infections, gastroenteritis, caused by ingestion of seafood or contact with Vibrio containing water. The most significant pathogenic Vibrio is $V$. cholerae, the aetiological agent of epidemic cholera, V. parahaemolyticus, responsible for seafood-associated gastroenteritis worldwide, and V. vulnificus, microorganism that may cause septicaemia and serious wound infections in susceptible individuals. All these tree pathogenic Vibrio species were detected in this study, confirming the wide distribution of these microorganisms in estuarine and coastal waters of Italy (Caburlotto et al., 2012; Gugliandolo et al., 2005; Masini et al., 2007; Ottaviani et al., 2013). There is substantial evidence that Vibrio-associated diseases are increasing worldwide, partially owing to increased geographic distribution of the pathogenic species favoured by climate changes and rising seawater temperatures (Baker-Austin et al., 2017; Baker-Austin et al., 2018; Vezzulli et al., 2016).

In this study Vibrio counts ranging from undetectable to $1.7 \times 10^{4} \mathrm{CFU} / 100 \mathrm{~mL}$ and an average concentrations of $4.7 \times 10^{3} \mathrm{CFU} / 100 \mathrm{~mL}$ were found in bathing waters. Concentrations up to $10^{5}$ and $10^{6} \mathrm{CFU} / 100 \mathrm{~mL}$ were previously reported in waters from the Tyrrhenian and Adriatic Sea (Bonadonna et al., 2002; Masini et al., 2007). Similarly, quantitative levels ranging ranging from undetectable to $2.4 \times 10^{4} \mathrm{CFU} / 100 \mathrm{~mL}$ or to $1.9 \times 10^{6} \mathrm{CFU} / 100 \mathrm{~mL}$ were described in recreational waters in The Netherland and in Germany, respectively (Boer et al., 2013; Schets et al., 2011). The presence and the quantitative levels of Vibrio spp. in water bodies depends on multiple environmental factors (Johnson, 2015). Although the effects of environmental parameters are highly species dependent, in general, temperature, salinity and $\mathrm{pH}$ are considered the most important. Indeed, in a survey carried out along the Adriatic Sea coasts (Bonadonna et al., 2002), not far from those considered in this study, a correlation between Vibrio counts and both temperature and salinity was observed. In this study a quantitative relation between water temperature and Vibrio 
concentration in bathing water was not observed probably for the low range of temperature recorded during the sampling period (from 19 to $29^{\circ} \mathrm{C}$ ). The same lack of correlation was also observed in the course of a study conducted from May to September in Netherlands (Schets et al., 2006). However, consistent with studies highlighting the seasonality of Vibrio presence and levels (Boer et al., 2013; Croci et al., 2001; Mookerjee et al., 2015; Paranjpye et al., 2015; Takemura et al., 2014), this study also recorded an increase in concentrations during the summer months (in August, in particular). No correlation between vibrios concentration and salinity was also observed. Probably in our study the salinity does not vary enough to identify a meaningful relationship. Salinity effects are often very complex, and can include covariance with other parameters, which makes it difficult to fully separate potential relationships (Johnson, 2015). In this study the $\mathrm{pH}$ values of bathing water were within a narrow range, from 8 to 8.68 . These conditions respected the limits reported by scientific literature for an optimal vibrios growth. In fact, it is known that Vibrio grows best under alkaline conditions and most species grow between pH 6.5 and 9.0 (Percival and Williams, 2014). In this investigation vibrios levels were positively associated to faecal indicators concentration; positive correlations were also found in other studies (Bonadonna et al., 2002; Viau et al., 2011). Nevertheless, the natural ubiquity of vibrios in seawaters makes their presence not necessarily related to faecal contamination events, then their relation with faecal indicators is complex and influenced by multiple factors (Bonadonna et al., 2002). Consequently, the adequacy of faecal indicators into represent Vibrio species in seawater is at present still object of discussion. In conclusion, the results of this study provide an overview of the viral contamination of seawaters used for recreational purposes in coastal waters. Detection of viruses in the absence of a high numbers of bacterial indicators confirms the need to carefully assess risks to human health in bathing waters affected by watercourses affected by sewage discharges. On the other hand, the presence of autochthonous vibrios can represent a constant and persistent health risk regardless of the presence of effluents along the coast, especially for immunocompromised people. 
Aichivirus was detected for the first time in marine waters, in greater abundance and higher frequency than other enteric viruses. Further studies are needed in order to investigate the potential of $\mathrm{AiV}$ to be used as indicator for marine waters.

The future Bathing Water Directive will have to carefully assess all microbial potential risks, also in the light of the ongoing climate changes that will affect not only the marine environmental conditions of the Mediterranean countries but also the Northern regions of Europe.

\section{Funding}

This work was supported by the Italian Ministery of Health, CCM Project "Supporto alla implementazione dell'analisi di rischio in acque potabili e balneazione e gestione del sistema informativo portale acque"

\section{Conflicts of interest}

There are no conflicts of interest to declare. 
Table 1: Primers and probes used in the study for real-time (RT)-qPCR and nested (RT)-PCR of viral targets and for PCR for species identification of Vibrio spp.

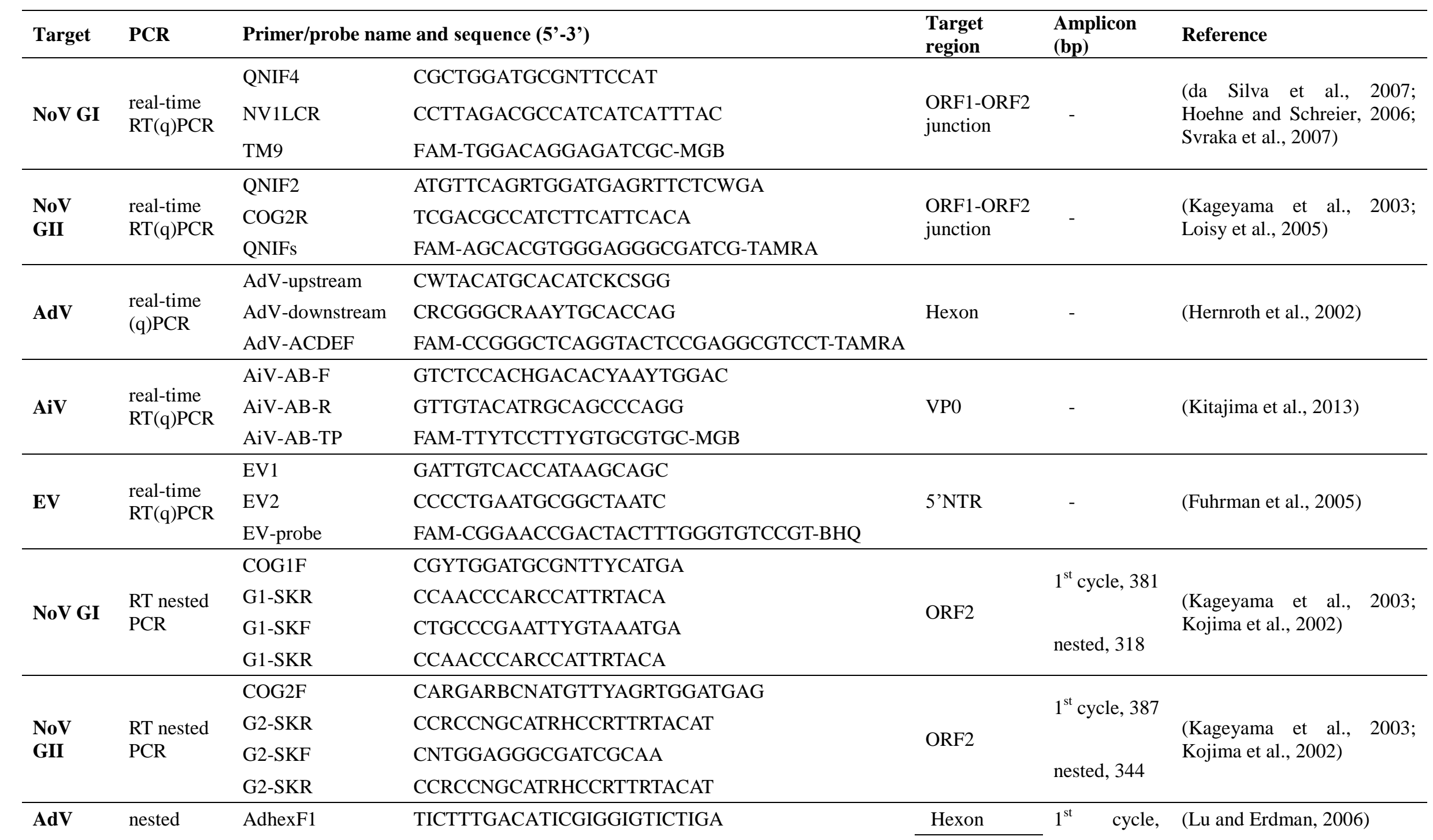


FAM: 6-carboxyfluorescein; TAMRA: 6-carboxytetramethylrhodamine; MGB: minor groove binder/non-fluorescent quencher; BHQ: black hole quencher 
Table 2: Results of the analysis for indicator microorganisms, enteric viruses and somatic coliphages

\begin{tabular}{|c|c|c|c|c|c|c|c|c|c|c|c|}
\hline \multirow[b]{2}{*}{ Site } & \multirow{2}{*}{ Sample ID } & \multirow{2}{*}{$\begin{array}{l}\text { Type of } \\
\text { water }\end{array}$} & \multirow{2}{*}{ Sampling date } & \multirow{2}{*}{$\begin{array}{c}\text { E. coli } \\
\text { (MPN/100 } \\
\text { mL) } \\
\end{array}$} & \multirow{2}{*}{$\begin{array}{c}\text { Enterococchi } \\
\text { (MPN/100m } \\
\text { L) } \\
\end{array}$} & \multicolumn{5}{|c|}{ Viruses quantification (g.c./L) and characterization } & \multirow{2}{*}{$\begin{array}{c}\text { Somatic } \\
\text { coliphages } \\
(\text { (PFU/100mL) }\end{array}$} \\
\hline & & & & & & NoV GI & NoV GII & $\mathbf{E V}$ & $\mathbf{A i V}$ & AdV & \\
\hline \multicolumn{12}{|c|}{ Riccione (Adriatic Sea) } \\
\hline $\mathrm{A}-0$ & 2667 & Estuary & $29 / 05 / 2018$ & $<1$ & $<1$ & - & - & - & - & - & - \\
\hline A-1 & 2668 & Bathing & $29 / 05 / 2018$ & $<1$ & $<1$ & - & - & - & - & - & - \\
\hline A-2 & 2669 & Bathing & $29 / 05 / 2018$ & $<1$ & $<1$ & - & - & - & - & - & - \\
\hline A- 0 & 2683 & Estuary & $18 / 06 / 2018$ & $<1$ & 15 & - & - & - & - & - & - \\
\hline A-1 & 2684 & Bathing & $18 / 06 / 2018$ & 445 & 104 & - & - & 0,4 & - & - & 20 \\
\hline A-2 & 2685 & Bathing & $18 / 06 / 2018$ & $<1$ & 10 & - & - & - & - & - & - \\
\hline A- 0 & 2700 & Estuary & $10 / 07 / 2018$ & 2827 & 387 & 13,0 & 0,6 & - & - & $A d V-41$ & 640 \\
\hline A-1 & 2701 & Bathing & $10 / 07 / 2018$ & 45 & 10 & - & 0,3 & - & - & - & 20 \\
\hline A-2 & 2702 & Bathing & $10 / 07 / 2018$ & 44 & 24 & - & 2,1 & - & $\begin{array}{l}1100,2 \\
A i V I-B\end{array}$ & - & - \\
\hline A- 0 & 2709 & Estuary & $27 / 08 / 2018$ & 1900 & 190 & - & & - & 964,7 & - & 220 \\
\hline A-1 & 2710 & Bathing & $27 / 08 / 2018$ & 2100 & 230 & - & 3,2 & - & - & - & 40 \\
\hline A-2 & 2711 & Bathing & $27 / 08 / 2018$ & $>4800$ & 150 & - & - & - & 121,5 & - & 260 \\
\hline A- -0 & 2720 & Estuary & $26 / 09 / 2018$ & 41 & 163 & - & - & - & $\begin{array}{c}1860,9 \\
A i V 1-B\end{array}$ & - & - \\
\hline A-1 & 2721 & Bathing & $26 / 09 / 2018$ & 34 & 185 & - & - & - & - & - & - \\
\hline A-2 & 2722 & Bathing & $26 / 09 / 2018$ & 261 & 55 & - & - & - & $\begin{array}{c}111,9 \\
A i V I-B\end{array}$ & - & 1 \\
\hline \multicolumn{12}{|c|}{ Ardea (Tyrrhenian Sea) } \\
\hline B-0 & 2664 & Estuary & $30 / 05 / 2018$ & 2406 & 275 & - & - & - & - & - & 200 \\
\hline B-1 & 2665 & Bathing & $30 / 05 / 2018$ & 111 & 40 & - & - & - & - & - & - \\
\hline B-2 & 2666 & Bathing & $30 / 05 / 2018$ & 58 & 52 & - & - & - & - & - & - \\
\hline B-0 & 2686 & Estuary & $24 / 06 / 2018$ & 17 & 76 & - & - & - & $A i V 1-B$ & - & 20 \\
\hline B-1 & 2687 & Bathing & $24 / 06 / 2018$ & 4 & 60 & - & - & - & - & - & 20 \\
\hline B-2 & 2688 & Bathing & $24 / 06 / 2018$ & $<1$ & $<1$ & - & - & - & $A i V 1-B$ & - & - \\
\hline
\end{tabular}




\begin{tabular}{|c|c|c|c|c|c|c|c|c|c|c|c|}
\hline B-0 & 2697 & Estuary & 04/07/2018 & 1300 & 107 & 0,8 & - & - & $\begin{array}{c}1203,0 \\
A i V 1-B\end{array}$ & $A d V-41$ & 180 \\
\hline B-1 & 2698 & Bathing & 04/07/2018 & 8 & 10 & - & - & - & $A i V 1-B$ & - & - \\
\hline B-2 & 2699 & Bathing & 04/07/2018 & 1600 & 150 & - & 0,1 & - & - & - & 20 \\
\hline B-0 & 2712 & Estuary & $28 / 08 / 2018$ & $>4800$ & 1900 & - & - & - & $\begin{array}{c}122,7 \\
A i V 1-B\end{array}$ & - & 3560 \\
\hline \multirow{2}{*}{$\begin{array}{l}\text { B-1 } \\
\text { B-2 }\end{array}$} & 2713 & Bathing & $28 / 08 / 2018$ & 270 & 370 & - & - & - & - & - & 320 \\
\hline & 2714 & Bathing & $28 / 08 / 2018$ & 870 & 920 & $\begin{array}{l}\text { NoV } \\
\text { GI.4 }\end{array}$ & - & - & - & - & 2120 \\
\hline B-0 & 2717 & Estuary & $25 / 09 / 2018$ & 1203 & 2827 & - & 0,2 & - & 144,7 & - & 12 \\
\hline B-1 & 2718 & Bathing & $25 / 09 / 2018$ & 354 & 304 & - & - & - & 413,2 & - & 16 \\
\hline B-2 & 2719 & Bathing & $25 / 09 / 2018$ & 28 & 49 & - & - & - & - & - & - \\
\hline
\end{tabular}

Samples exceeding the limits of EU legislation for bathing waters are highlighted in bold.

Results of real-time (RT)-qPCR are reported as concentrations of the target virus (c.g./L); results of the nested (RT)-PCR (in italics) are reported as the type/genotype detected. Samples in which the viral target was not detected are reported as "-". 
Table 3: Qualitative and quantitative assessment of Vibrio spp. in the monitored costal sites

1

2

3

4

5

6

\begin{tabular}{|c|c|c|c|c|c|c|}
\hline \multirow{2}{*}{ Site } & \multirow{2}{*}{$\begin{array}{l}\text { Vibrio spp. } \\
\text { positive } \\
\text { samples }(\%)\end{array}$} & \multicolumn{4}{|c|}{$\begin{array}{l}\text { Vibrio spp. concentration } \\
\text { (CFU/100 mL) }\end{array}$} & \multirow{2}{*}{ Vibrio species detected } \\
\hline & & Min & Max & Avg & SD & \\
\hline \multicolumn{7}{|c|}{ Riccione (Adriatic Sea) } \\
\hline Estuary & $3 / 5(60)$ & $<1$ & $1.0 \times 10^{4}$ & $2.9 \times 10^{3}$ & $4.4 \times 10^{3}$ & $\begin{array}{l}\text { V.campbellii, V.cholerae, V.harveyi, } \\
\text { V.owensii/V.hyugaensis, } \\
\text { V.parahaemolyticus, V.vulnificus }\end{array}$ \\
\hline Bathing & $8 / 10(80)$ & $<1$ & $1.7 \times 10^{4}$ & $4.2 \times 10^{3}$ & $6.4 \times 10^{3}$ & $\begin{array}{l}\text { V.alginolyticus, V.campbellii, } \\
\text { V.cholerae, V.diabolicus, V.harveyi, } \\
\text { V.owensii/V.hyugaensis, } \\
\text { V.parahaemolyticus }\end{array}$ \\
\hline \multicolumn{7}{|c|}{ Ardea (Tyrrhenian Sea) } \\
\hline Estuary & $5 / 5(100)$ & $1.6 \times 10^{2}$ & $5.8 \times 10^{3}$ & $2.5 \times 10^{3}$ & $2.7 \times 10^{3}$ & $\begin{array}{l}\text { V.alginolyticus, V.campbellii, } \\
\text { V.cholerae, V.harveyi, V.vulnificus }\end{array}$ \\
\hline Bathing & $9 / 10(90)$ & $<1$ & $4.3 \times 10^{3}$ & $1.3 \times 10^{3}$ & $1.4 \times 10^{3}$ & $\begin{array}{l}\text { V.alginolyticus, V.campbellii, } \\
\text { V.cholerae, V.diabolicus, V.harveyi, } \\
\text { V.owensii/V.hyugaensis, } \\
\text { V.parahaemolyticus, V.rotiferianius }\end{array}$ \\
\hline \multicolumn{7}{|l|}{ Total } \\
\hline Estuary & $8 / 10(80)$ & $<1$ & $1.0 \times 10^{4}$ & $2.7 \times 10^{3}$ & $3.5 \times 10^{3}$ & $\begin{array}{l}\text { V.alginolyticus, V.campbellii, } \\
\text { V.cholerae, V.harveyi, } \\
\text { V.owensii/V.hyugaensis, } \\
\text { V.parahaemolyticus, V.vulnificus }\end{array}$ \\
\hline Bathing & $17 / 20(85)$ & $<1$ & $1.7 \times 10^{4}$ & $2.8 \times 10^{3}$ & $4.7 \times 10^{3}$ & $\begin{array}{l}\text { V.alginolyticus, V.campbellii, } \\
\text { V.cholerae, V.diabolicus, V.harveyi, } \\
\text { V.owensii/V.hyugaensis, } \\
\text { V.parahaemolyticus, V.rotiferianius }\end{array}$ \\
\hline
\end{tabular}

Min = minimum value $;$ Max = maximum value $;$ Avg $=$ average $; \mathrm{SD}=$ standard deviation 
Figure 1: GIS map of the collection sites

Figure 2: E. coli and Enterococci values of bathing and non-bathing waters

Figure 3: Vibrio spp. loads in the bathing waters of the two sampling sites in relation to the environmental parameters.

Panel A: bathing waters, Panel B: non-bathing waters. Vibrio spp. counts and environmental parameters (temperature, salinity and $\mathrm{pH}$ ) are reported as the average of the values obtained in the two sampling points in bathing waters 
Abdelzaher,A.M., Wright,M.E., Ortega,C., Hasan,A.R., Shibata,T., Solo-Gabriele,H.M., Kish,J., Withum,K., He,G., Elmir,S.M., Bonilla,J.A., Bonilla,T.D., Palmer,C.J., Scott,T.M., Lukasik,J., Harwood,V.J., McQuaig,S., Sinigalliano,C.D., Gidley,M.L., Wanless,D., Plano,L.R., Garza,A.C., Zhu,X., Stewart,J.R., Dickerson,J.W., Yampara-Iquise,H., Carson,C., Fleisher,J.M. and Fleming,L.E.: 2011, 'Daily measures of microbes and human health at a non-point source marine beach', J Water Health. 9, 443-457.

Alcala,A., Vizzi,E., Rodriguez-Diaz,J., Zambrano,J.L., Betancourt,W. and Liprandi,F.: 2010, 'Molecular detection and characterization of Aichi viruses in sewage-polluted waters of Venezuela', Appl. Environ. Microbiol. 76, 4113-4115.

Allard,A. and Vantarakis,A.: 2017, 'Adenoviruses', in J.S.Meschke and R.Girones (eds.), Global Water Pathogens, Michigan State University, E. Lansing, MI, UNESCO..

Andersson,Y. and Ekdahl,K.: 2006, 'Wound infections due to Vibrio cholerae in Sweden after swimming in the Baltic Sea, summer 2006', Euro. Surveill. 11, E060803.

Badley,A., Phillips,B., Haldane,D.J. and Dalton,M.T.: 1990, 'Pathogenic marine vibrio species in selected Nova Scotian recreational coastal waters', Can. J Public Health. 81, 263-267.

Baker-Austin,C., Oliver,J.D., Alam,M., Ali,A., Waldor,M.K., Qadri,F. and Martinez-Urtaza,J.: 2018, 'Vibrio spp. infections', Nat. Rev. Dis. Primers. 4, 8.

Baker-Austin,C., Trinanes,J., Gonzalez-Escalona,N. and Martinez-Urtaza,J.: 2017, 'Non-Cholera Vibrios: The Microbial Barometer of Climate Change', Trends Microbiol. 25, 76-84.

Baker-Austin,C., Trinanes,J.A., Salmenlinna,S., Lofdahl,M., Siitonen,A., Taylor,N.G. and Martinez-Urtaza,J.: 2016, 'Heat Wave-Associated Vibriosis, Sweden and Finland, 2014', Emerg. Infect. Dis. 22, 1216-1220.

Begier,E.M., Oberste,M.S., Landry,M.L., Brennan,T., Mlynarski,D., Mshar,P.A., Frenette,K., Rabatsky-Ehr,T., Purviance,K., Nepaul,A., Nix,W.A., Pallansch,M.A., Ferguson,D., Cartter,M.L. and Hadler,J.L.: 2008, 'An outbreak of concurrent echovirus 30 and coxsackievirus A1 infections associated with sea swimming among a group of travelers to Mexico', Clin. Infect. Dis. 47, 616-623.

Betancourt, W. Q and Shulman, L. M. Polioviruses and other Enteroviruses. 2019. In: J.B. Rose and B. Jiménez-Cisneros, (eds) Global Water Pathogen Project. http://www.waterpathogens.org (J.S Meschke, and R. Girones (eds) Part 3 Viruses) http://www.waterpathogens.org/book/poliovirusesand-other-enteroviruses Michigan State University, E. Lansing, MI, UNESCO. https://doi.org/10.14321/waterpathogens.15.

Ref Type: Online Source

Boer,S.I., Heinemeyer,E.A., Luden,K., Erler,R., Gerdts,G., Janssen,F. and Brennholt,N.: 2013, 'Temporal and spatial distribution patterns of potentially pathogenic Vibrio spp. at recreational beaches of the German north sea', Microb. Ecol. 65, 1052-1067.

Bonadonna,L., Briancesco,R., Coccia,A.M., Semproni,M. and Stewardson,D.: 2002, 'Occurrence of potential bacterial pathogens in coastal areas of the Adriatic Sea', Environ. Monit. Assess. 77, 31-49. 
Bonadonna, L. and La Rosa, G. A Review and Update on Waterborne Viral Diseases Associated with Swimming Pools. Int.J.Environ.Res.Public Health 16[2], 166. 2019. Ref Type: Journal (Full)

Burutaran,L., Lizasoain,A., Garcia,M., Tort,L.F., Colina,R. and Victoria,M.: 2016, 'Detection and Molecular Characterization of Aichivirus 1 in Wastewater Samples from Uruguay', Food Environ. Virol. 8, 13-17.

Caburlotto,G., Bianchi,F., Gennari,M., Ghidini,V., Socal,G., Aubry,F.B., Bastianini,M., Tafi,M. and Lleo,M.M.: 2012, 'Integrated evaluation of environmental parameters influencing Vibrio occurrence in the coastal Northern Adriatic Sea (Italy) facing the Venetian lagoon', Microb. Ecol. 63, 20-31.

Carducci, A., Rovini, E., and Verani, M. Viral removal by wastewater treatment: monitoring of indicators and pathogens. Food and Environmental Virology 1[2], 85-91. 2009.

Ref Type: Journal (Full)

Costafreda,M.I., Bosch,A. and Pinto,R.M.: 2006, 'Development, evaluation, and standardization of a real-time TaqMan reverse transcription-PCR assay for quantification of hepatitis A virus in clinical and shellfish samples', Appl. Environ. Microbiol. 72, 3846-3855.

Croci,L., Serratore,P., Cozzi,L., Stacchini,A., Milandri,S., Suffredini,E. and Toti,L.: 2001, 'Detection of Vibrionaceae in mussels and in their seawater growing area', Lett. Appl. Microbiol. 32, 57-61.

da Silva,A.K., Le Saux,J.C., Parnaudeau,S., Pommepuy,M., Elimelech,M. and Le Guyader,F.: 2007, 'Evaluation of removal of noroviruses during wastewater treatment, using real-time reverse transcription-PCR: different behaviors of genogroups I and II', Appl. Environ. Microbiol. 73, 78917897.

De Giglio,O., Caggiano,G., Bagordo,F., Barbuti,G., Brigida,S., Lugoli,F., Grassi,T., La,R.G., Lucentini,L., Uricchio,V.F., De,D.A. and Montagna,M.T.: 2017, 'Enteric Viruses and Fecal Bacteria Indicators to Assess Groundwater Quality and Suitability for Irrigation', Int J Environ. Res Public Health. 14.

DeFlorio-Barker,S., Wing,C., Jones,R.M. and Dorevitch,S.: 2018, 'Estimate of incidence and cost of recreational waterborne illness on United States surface waters', Environ. Health. 17, 3.

Di Martino,B., Di,P.F., Ceci,C., Di,F.E. and Marsilio,F.: 2013, 'Molecular detection of Aichi virus in raw sewage in Italy', Arch. Virol. 158, 2001-2005.

Dumontet,S., Krovacek,K., Svenson,S.B., Pasquale,V., Baloda,S.B. and Figliuolo,G.: 2000, 'Prevalence and diversity of Aeromonas and Vibrio spp. in coastal waters of Southern Italy', Comp Immunol. Microbiol. Infect. Dis. 23, 53-72.

Dziuban,E.J., Liang,J.L., Craun,G.F., Hill,V., Yu,P.A., Painter,J., Moore,M.R., Calderon,R.L., Roy,S.L. and Beach,M.J.: 2006, 'Surveillance for waterborne disease and outbreaks associated with recreational water--United States, 2003-2004', MMWR Surveill Summ. 55, 1-30.

Esteves,K., Hervio-Heath,D., Mosser,T., Rodier,C., Tournoud,M.G., Jumas-Bilak,E., Colwell,R.R. and Monfort,P.: 2015, 'Rapid proliferation of Vibrio parahaemolyticus, Vibrio vulnificus, and Vibrio cholerae during freshwater flash floods in French Mediterranean coastal lagoons', Appl. Environ. Microbiol. 81, 7600-7609. 
Figueras,M.J. and Borrego,J.J.: 2010, 'New perspectives in monitoring drinking water microbial quality', Int J Environ. Res Public Health. 7, 4179-4202.

Figueras,M.J., Polo,F., Inza,I. and Guarro,J.: 1997, 'Past, present and future perspectives of the EU bathing water directive', Mar Pollut Bull. 34, 148-156.

Frank,C., Littman,M., Alpers,K. and Hallauer,J.: 2006, 'Vibrio vulnificus wound infections after contact with the Baltic Sea, Germany', Euro. Surveill. 11, E060817.

Froelich,B.A. and Noble,R.T.: 2016, 'Vibrio bacteria in raw oysters: managing risks to human health', Philos. Trans. R. Soc. Lond B Biol. Sci. 371.

Fuhrman,J.A., Liang,X. and Noble,R.T.: 2005, 'Rapid detection of enteroviruses in small volumes of natural waters by real-time quantitative reverse transcriptase PCR', Appl. Environ. Microbiol. 71, 4523-4530.

Fusco,G., Di Bartolo,I., Cioffi,B., Ianiro,G., Palermo,P., Monini,M. and Amoroso,M.G.: 2017, 'Prevalence of Foodborne Viruses in Mussels in Southern Italy', Food Environ. Virol. 9, 187-194.

Gerba,C.P., Gramos,D.M. and Nwachuku,N.: 2002, 'Comparative inactivation of enteroviruses and adenovirus 2 by UV light', Appl. Environ. Microbiol. 68, 5167-5169.

Gomila,M., Solis,J.J., David,Z., Ramon,C. and Lalucat,J.: 2008, 'Comparative reductions of bacterial indicators, bacteriophage-infecting enteric bacteria and enteroviruses in wastewater tertiary treatments by lagooning and UV-radiation', Water Sci Technol. 58, 2223-2233.

Griffith,J.F., Weisberg,S.B., Arnold,B.F., Cao,Y., Schiff,K.C. and Colford,J.M., Jr.: 2016, 'Epidemiologic evaluation of multiple alternate microbial water quality monitoring indicators at three California beaches', Water Res. 94, 371-381.

Gugliandolo,C., Carbone,M., Fera,M.T., Irrera,G.P. and Maugeri,T.L.: 2005, 'Occurrence of potentially pathogenic vibrios in the marine environment of the Straits of Messina (Italy)', Mar. Pollut. Bull. 50, 692-697.

Haramoto,E., Kitajima,M., Hata,A., Torrey,J.R., Masago,Y., Sano,D. and Katayama,H.: 2018, 'A review on recent progress in the detection methods and prevalence of human enteric viruses in water', Water Res. 135, 168-186.

Hernroth,B.E., Conden-Hansson,A.C., Rehnstam-Holm,A.S., Girones,R. and Allard,A.K.: 2002, 'Environmental factors influencing human viral pathogens and their potential indicator organisms in the blue mussel, Mytilus edulis: the first Scandinavian report', Appl. Environ. Microbiol. 68, 45234533.

Hoehne,M. and Schreier,E.: 2006, 'Detection of Norovirus genogroup I and II by multiplex realtime RT- PCR using a 3'-minor groove binder-DNA probe', BMC. Infect. Dis. 6, 69.

Huehn,S., Eichhorn,C., Urmersbach,S., Breidenbach,J., Bechlars,S., Bier,N., Alter,T., Bartelt,E., Frank,C., Oberheitmann,B., Gunzer,F., Brennholt,N., Boer,S., Appel,B., Dieckmann,R. and Strauch,E.: 2014, 'Pathogenic vibrios in environmental, seafood and clinical sources in Germany', Int J Med Microbiol. 304, 843-850.

ISO. ISO 15216-1:2017. Microbiology of the food chain -- Horizontal method for determination of hepatitis A virus and norovirus using real-time RT-PCR -- Part 1: Method for quantification. 2017. 
Johnson,C.N.: 2015, 'Influence of Environmental Factors on Vibrio spp. in Coastal Ecosystems',

\section{Microbiol. Spectr. 3.}

Kageyama,T., Kojima,S., Shinohara,M., Uchida,K., Fukushi,S., Hoshino,F.B., Takeda,N. and Katayama,K.: 2003, 'Broadly reactive and highly sensitive assay for Norwalk-like viruses based on real-time quantitative reverse transcription- PCR', Journal of Clinical Microbiology. 41, 1548-1557.

Katayama,H., Haramoto,E., Oguma,K., Yamashita,H., Tajima,A., Nakajima,H. and Ohgaki,S.: 2008, 'One-year monthly quantitative survey of noroviruses, enteroviruses, and adenoviruses in wastewater collected from six plants in Japan', Water Res. 42, 1441-1448.

Ki,J.S., Zhang,R., Zhang,W., Huang,Y.L. and Qian,P.Y.: 2009, 'Analysis of RNA polymerase beta subunit (rpoB) gene sequences for the discriminative power of marine Vibrio species', Microb. Ecol. 58, 679-691.

Kirchberger,P.C., Orata,F.D., Barlow,E.J., Kauffman,K.M., Case,R.J., Polz,M.F. and Boucher,Y.: 2016, 'A Small Number of Phylogenetically Distinct Clonal Complexes Dominate a Coastal Vibrio cholerae Population', Appl. Environ. Microbiol. 82, 5576-5586.

Kitajima,M. and Gerba,C.P.: 2015a, 'Aichi virus 1: environmental occurrence and behavior', Pathogens. 4, 256-268.

Kitajima,M. and Gerba,C.P.: 2015b, 'Aichi virus 1: environmental occurrence and behavior', Pathogens. 4, 256-268.

Kitajima,M., Haramoto,E., Phanuwan,C. and Katayama,H.: 2011, 'Prevalence and genetic diversity of Aichi viruses in wastewater and river water in Japan', Appl. Environ. Microbiol. 77, 2184-2187.

Kitajima,M., Hata,A., Yamashita,T., Haramoto,E., Minagawa,H. and Katayama,H.: 2013, 'Development of a reverse transcription-quantitative PCR system for detection and genotyping of aichi viruses in clinical and environmental samples', Appl. Environ. Microbiol. 79, 3952-3958.

Kojima,S., Kageyama,T., Fukushi,S., Hoshino,F.B., Shinohara,M., Uchida,K., Natori,K., Takeda,N. and Katayama,K.: 2002, 'Genogroup-specific PCR primers for detection of Norwalk-like viruses', J. Virol. Methods. 100, 107-114.

La Rosa G., Pourshaban,M., Iaconelli,M. and Muscillo,M.: 2010, 'Quantitative real-time PCR of enteric viruses in influent and effluent samples from wastewater treatment plants in Italy', Ann. Ist. Super. Sanita. 46, 266-273.

La Rosa G. and Suffredini,E.: 2018, 'Adenovirus', in Dongyou Liu (ed.), Handbook of Foodborne Diseases, CRC press.

La Rosa,G., Della,L.S., Iaconelli,M., Proroga,Y.T., De,M.D., Martella,V. and Suffredini,E.: 2017a, 'Detection of Norovirus GII.17 Kawasaki 2014 in Shellfish, Marine Water and Underwater Sewage Discharges in Italy', Food Environ. Virol.

La Rosa,G., Della,L.S., Iaconelli,M., Proroga,Y.T.R., De,M.D., Martella,V. and Suffredini,E.: 2017b, 'Detection of Norovirus GII.17 Kawasaki 2014 in Shellfish, Marine Water and Underwater Sewage Discharges in Italy', Food Environ. Virol. 9, 326-333.

La Rosa,G., Fratini,M., Della,L.S., Iaconelli,M. and Muscillo,M.: 2012, 'Emerging and potentially emerging viruses in water environments', Ann. Ist. Super. Sanita. 48, 397-406. 
La Rosa,G., Sanseverino,I., Della Libera,S., Iaconelli,M., Ferrero,V.E.V., Barra,C.A. and the Tiber river, Italy', Lett. Appl. Microbiol.

Leonard,A.F.C., Singer,A., Ukoumunne,O.C., Gaze,W.H. and Garside,R.: 2018, 'Is it safe to go back into the water? A systematic review and meta-analysis of the risk of acquiring infections from recreational exposure to seawater', Int J Epidemiol. 47, 572-586.

Lodder,W.J., Rutjes,S.A., Takumi,K. and de Roda Husman,A.M.: 2013, 'Aichi virus in sewage and surface water, the Netherlands', Emerg. Infect. Dis. 19, 1222-1230.

Loisy,F., Atmar,R.L., Guillon,P., Le Cann,P., Pommepuy,M. and Le Guyader,F.S.: 2005, 'Real-time RT-PCR for norovirus screening in shellfish', J. Virol. Methods. 123, 1-7.

Love,D.C., Rodriguez,R.A., Gibbons,C.D., Griffith,J.F., Yu,Q., Stewart,J.R. and Sobsey,M.D.: 2014, 'Human viruses and viral indicators in marine water at two recreational beaches in Southern California, USA', $J$ Water Health. 12, 136-150.

Lu,X. and Erdman,D.D.: 2006, 'Molecular typing of human adenoviruses by PCR and sequencing of a partial region of the hexon gene', Arch. Virol. 151, 1587-1602.

Lucena,F., Mendez,X., Moron,A., Calderon,E., Campos,C., Guerrero,A., Cardenas,M., Gantzer,C., Shwartzbrood,L., Skraber,S. and Jofre,J.: 2003, 'Occurrence and densities of bacteriophages proposed as indicators and bacterial indicators in river waters from Europe and South America', J. Appl. Microbiol. 94, 808-815.

Masini,L., De,G.G., Principi,F., Mengarelli,C. and Ottaviani,D.: 2007, 'Research and characterization of pathogenic vibrios from bathing water along the Conero Riviera (Central Italy)', Water Res. 41, 4031-4040.

Mookerjee,S., Batabyal,P., Sarkar,M.H. and Palit,A.: 2015, 'Seasonal Prevalence of Enteropathogenic Vibrio and Their Phages in the Riverine Estuarine Ecosystem of South Bengal', PLoS. One. 10, e0137338.

Neogi,S.B., Lara,R., Alam,M., Harder,J., Yamasaki,S. and Colwell,R.R.: 2018, 'Environmental and hydroclimatic factors influencing Vibrio populations in the estuarine zone of the Bengal delta', Environ. Monit. Assess. 190, 565.

Odeyemi,O.A.: 2016, 'Incidence and prevalence of Vibrio parahaemolyticus in seafood: a systematic review and meta-analysis', Springerplus. 5, 464.

Oh,D.Y., Silva,P.A., Hauroeder,B., Diedrich,S., Cardoso,D.D. and Schreier,E.: 2006, 'Molecular characterization of the first Aichi viruses isolated in Europe and in South America', Arch. Virol. 151, 1199-1206.

Ortega,C., Solo-Gabriele,H.M., Abdelzaher,A., Wright,M., Deng,Y. and Stark,L.M.: 2009, 'Correlations between microbial indicators, pathogens, and environmental factors in a subtropical estuary', Mar. Pollut. Bull. 58, 1374-1381.

Ottaviani,D., Leoni,F., Rocchegiani,E., Mioni,R., Costa,A., Virgilio,S., Serracca,L., Bove,D., Canonico,C., Di,C.A., Masini,L., Potenziani,S., Caburlotto,G., Ghidini,V. and Lleo,M.M.: 2013, 'An extensive investigation into the prevalence and the genetic and serological diversity of toxigenic Vibrio parahaemolyticus in Italian marine coastal waters', Environ. Microbiol. 15, 1377-1386. 
Paranjpye,R.N., Nilsson,W.B., Liermann,M., Hilborn,E.D., George,B.J., Li,Q., Bill,B.D., distribution of Vibrio parahaemolyticus in the Pacific Northwest of the USA', FEMS Microbiol. Ecol. 91.

Pellegrinelli,L., Binda,S., Chiaramonte,I., Primache,V., Fiore,L., Battistone,A., Fiore,S., Gambino,M., Bubba,L. and Barbi,M.: 2013, 'Detection and distribution of culturable Human Enteroviruses through environmental surveillance in Milan, Italy', J. Appl. Microbiol. 115, 12311239.

Pellegrinelli,L., Bubba,L., Primache,V., Pariani,E., Battistone,A., Delogu,R., Fiore,S. and Binda,S.: 2017, 'Surveillance of poliomyelitis in Northern Italy: Results of acute flaccid paralysis surveillance and environmental surveillance, 2012-2015', Hum. Vaccin. Immunother. 13, 332-338.

Pennino,F., Nardone,A., Montuori,P., Aurino,S., Torre,I., Battistone,A., Delogu,R., Buttinelli,G., Fiore,S., Amato,C. and Triassi,M.: 2018, 'Large-Scale Survey of Human Enteroviruses in Wastewater Treatment Plants of a Metropolitan Area of Southern Italy', Food Environ. Virol. 10, 187-192.

Percival,S. and Williams,D.: 2014, 'Vibrio', Microbiology of Waterborne Diseases (Second Edition), 2014, pp. 237-248.

Pianetti,A., Baffone,W., Citterio,B., Casaroli,A., Bruscolini,F. and Salvaggio,L.: 2000, 'Presence of enteroviruses and reoviruses in the waters of the Italian coast of the Adriatic Sea', Epidemiol. Infect. 125, 455-462.

Rajtar,B., Majek,M., Polanski,L. and Polz-Dacewicz,M.: 2008, 'Enteroviruses in water environment--a potential threat to public health', Ann. Agric. Environ. Med. 15, 199-203.

Romalde,J.L., Dieguez,A.L., Lasa,A. and Balboa,S.: 2014, 'New Vibrio species associated to molluscan microbiota: a review', Front Microbiol. 4, 413.

Schets,F.M., van den Berg,H.H., Demeulmeester,A.A., van,D.E., Rutjes,S.A., van Hooijdonk,H.J. and de Roda Husman,A.M.: 2006, 'Vibrio alginolyticus infections in the Netherlands after swimming in the North Sea', Euro. Surveill. 11, E061109.

Schets,F.M., van den Berg,H.H., Marchese,A., Garbom,S. and de Roda Husman,A.M.: 2011, 'Potentially human pathogenic vibrios in marine and fresh bathing waters related to environmental conditions and disease outcome', Int J Hyg. Environ. Health. 214, 399-406.

Schets,F.M., van den Berg,H.H.J.L., Vennema,H., Pelgrim,M.T.M., Colle,C., Rutjes,S.A. and Lodder,W.J.: 2018, 'Norovirus Outbreak Associated with Swimming in a Recreational Lake Not Influenced by External Human Fecal Sources in The Netherlands, August 2012', Int J Environ. Res Public Health. 15.

Sdiri-Loulizi,K., Hassine,M., Aouni,Z., Gharbi-Khelifi,H., Sakly,N., Chouchane,S., Guediche,M.N., Pothier,P., Aouni,M. and Ambert-Balay,K.: 2010, 'First molecular detection of Aichi virus in sewage and shellfish samples in the Monastir region of Tunisia', Arch. Virol. 155, 1509-1513.

Semenza,J.C., Trinanes,J., Lohr,W., Sudre,B., Lofdahl,M., Martinez-Urtaza,J., Nichols,G.L. and Rocklov,J.: 2017, 'Environmental Suitability of Vibrio Infections in a Warming Climate: An Early Warning System', Environ. Health Perspect. 125, 107004. 
Shuval,H.: 2003, 'Estimating the global burden of thalassogenic diseases: human infectious diseases caused by wastewater pollution of the marine environment', $J$ Water Health. 1, 53-64.

Sinclair,R.G., Jones,E.L. and Gerba,C.P.: 2009, 'Viruses in recreational water-borne disease outbreaks: a review', J. Appl. Microbiol.

Suffredini,E. and Caburlotto,G.: 2015, ' Vibrios: types, properties, and determination', in B.Caballero, P.Finglas and F.Toldrà (eds.), Encyclopedia of food and health, pp. 413-417.

Suffredini,E., Cozzi,L., Ciccaglioni,G. and Croci,L.: 2014, 'Development of a colony hybridization method for the enumeration of total and potentially enteropathogenic Vibrio parahaemolyticus in shellfish', Int J Food Microbiol. 186, 22-31.

Svraka,S., Duizer,E., Vennema,H., de Bruin,E., van,d., V, Dorresteijn,B. and Koopmans,M.P.: 2007, 'Etiological role of viruses in outbreaks of acute gastroenteritis in The Netherlands from 1994 through 2005', J. Clin. Microbiol. 45, 1389-1394.

Takemura,A.F., Chien,D.M. and Polz,M.F.: 2014, 'Associations and dynamics of Vibrionaceae in the environment, from the genus to the population level', Front Microbiol. 5, 38.

Verani,M., Federigi,I., Donzelli,G., Cioni,L. and Carducci,A.: 2019, 'Human adenoviruses as waterborne index pathogens and their use for Quantitative Microbial Risk Assessment', Sci. Total Environ. 651, 1469-1475.

Vezzulli,L., Grande,C., Reid,P.C., Helaouet,P., Edwards,M., Hofle,M.G., Brettar,I., Colwell,R.R. and Pruzzo,C.: 2016, 'Climate influence on Vibrio and associated human diseases during the past half-century in the coastal North Atlantic', Proc. Natl. Acad. Sci. U. S. A. 113, E5062-E5071.

Viau,E.J., Goodwin,K.D., Yamahara,K.M., Layton,B.A., Sassoubre,L.M., Burns,S.L., Tong,H.I., Wong,S.H., Lu,Y. and Boehm,A.B.: 2011, 'Bacterial pathogens in Hawaiian coastal streams-associations with fecal indicators, land cover, and water quality', Water Res. 45, 3279-3290.

Wiedenmann,A., Kruger,P., Dietz,K., Lopez-Pila,J.M., Szewzyk,R. and Botzenhart,K.: 2006, 'A randomized controlled trial assessing infectious disease risks from bathing in fresh recreational waters in relation to the concentration of Escherichia coli, intestinal enterococci, Clostridium perfringens, and somatic coliphages', Environ. Health Perspect. 114, 228-236.

Wyer,M.D., Wyn-Jones,A.P., Kay,D., Au-Yeung,H.K., Girones,R., Lopez-Pila,J., de Roda Husman,A.M., Rutjes,S. and Schneider,O.: 2012, 'Relationships between human adenoviruses and faecal indicator organisms in European recreational waters', Water Res. 46, 4130-4141.

Wyn-Jones,A.P., Carducci,A., Cook,N., D'Agostino,M., Divizia,M., Fleischer,J., Gantzer,C., Gawler,A., Girones,R., Holler,C., de Roda Husman,A.M., Kay,D., Kozyra,I., Lopez-Pila,J., Muscillo,M., Nascimento,M.S., Papageorgiou,G., Rutjes,S., Sellwood,J., Szewzyk,R. and Wyer,M.: 2011, 'Surveillance of adenoviruses and noroviruses in European recreational waters', Water Res. 45, 1025-1038.

Yoder,J., Roberts,V., Craun,G.F., Hill,V., Hicks,L.A., Alexander,N.T., Radke,V., Calderon,R.L., Hlavsa,M.C., Beach,M.J. and Roy,S.L.: 2008a, 'Surveillance for waterborne disease and outbreaks associated with drinking water and water not intended for drinking--United States, 2005-2006', MMWR Surveill Summ. 57, 39-62. 
Yoder,J.S., Blackburn,B.G., Craun,G.F., Hill,V., Levy,D.A., Chen,N., Lee,S.H., Calderon,R.L. and Beach,M.J.: 2004, 'Surveillance for waterborne-disease outbreaks associated with recreational water--United States, 2001-2002', MMWR Surveill Summ. 53, 1-22.

Yoder,J.S., Hlavsa,M.C., Craun,G.F., Hill,V., Roberts,V., Yu,P.A., Hicks,L.A., Alexander,N.T., Calderon,R.L., Roy,S.L. and Beach,M.J.: 2008b, 'Surveillance for waterborne disease and outbreaks associated with recreational water use and other aquatic facility-associated health events--United States, 2005-2006', MMWR Surveill Summ. 57, 1-29.

Zlot,A., Simckes,M., Vines,J., Reynolds,L., Sullivan,A., Scott,M.K., McLuckie,J.M., Kromer,D., Hill,V.R., Yoder,J.S. and Hlavsa,M.C.: 2015, 'Norovirus Outbreak Associated With a Natural Lake Used for Recreation-Oregon, 2014', Am. J Transplant. 15, 2001-2005.

Zoll,G.J., Melchers,W.J., Kopecka,H., Jambroes,G., van der Poel,H.J. and Galama,J.M.: 1992, 'General primer-mediated polymerase chain reaction for detection of enteroviruses: application for diagnostic routine and persistent infections', J Clin. Microbiol. 30, 160-165. 